\title{
Physiological Behavior of Potato cv. Tollocan at Diverse Types of Salinity
}

\author{
Edgar I. Sánchez Bernal ${ }^{1}$, Marco A. Camacho Escobar ${ }^{1}$, Anastacio Rodríguez León ${ }^{2}$ \\ \& Héctor M. Ortega Escobar ${ }^{3}$ \\ ${ }^{1}$ Institute of Ecology, Universidad del Mar, Puerto Escondido, Oaxaca, Mexico \\ ${ }^{2}$ Resources Institute, Universidad del Mar, Puerto Escondido, Oaxaca, Mexico \\ ${ }^{3}$ Hydrosciences Program, Colegio de Postgraduados, Montecillo, Mexico \\ Correspondence: Edgar I. Sánchez Bernal, Institute of Ecology, Universidad del Mar Campus Puerto Escondido, \\ Oaxaca, Mexico. Tel: 52-1954-582-4990. E-mail: edgarivansb@zicatela.umar.mx
}

Received: September 27, 2012 Accepted: December 5, 2012 Online Published: January 10, 2013

doi:10.5539/jps.v2n1p120

URL: http://dx.doi.org/10.5539/jps.v2n1p120

\begin{abstract}
The objective of this experiment was to analyze the growth of Solanum tuberosum cv. Tollocan under sulphate-hydrochloric, hydrochloric-sulphate and sulphate-sodium soil salinities at various concentrations, as occurs in soils where potatoes are grown in Mexico (Toluca Valley, highlands of Nuevo León and foothills of the Laguna del Carmen in Tlaxcala) with damages to the crop yield by salt stress. For this purpose a greenhouse experiment was conducted with randomized complete block design composed by three treatments and three repetitions. This consisted of planting tubers and growing plants in pots with perlite, and subjecting them to irrigation with saline solutions prepared in the laboratory at electrical conductivities from 0 to $15.0 \mathrm{dS} \mathrm{m} \mathrm{m}^{-1}$, whose ionic relations of $\frac{\mathrm{Cl}^{-1}}{\mathrm{SO}_{4}^{-2}} \approx 1.5, \frac{\mathrm{Cl}^{-1}}{\mathrm{SO}_{4}^{-2}} \approx 0.6, \frac{\mathrm{HCO}_{3}^{-1}}{\mathrm{Cl}^{-1}+\mathrm{SO}_{4}^{-2}} \approx 2.0$ allowed simulating those induced by salinities in field. The physiological behavior of plants in the vegetative stage of tuberization and tuber filling was evaluated using as variables the number of leaves, leaf area index, net photosynthesis, shoot length, root length and number and diameter of tubers per plant. Likewise its biomass accumulation and tolerance to each salinity was determined. Results indicate a severe reduction in growth, presence of secondary tubers and formation of small potato tubers in plants subjected to sulphate-hydrochloric and hydrochloric sulphate salinities from an electrical conductivity $>6.0 \mathrm{dS} \mathrm{m}^{-1}$, so that $\mathrm{cv}$. Tollocan is considered sensitive to these conditions. The reduction was more drastic and significant with $\mathrm{P}=0.05$ in sulphate-sodium salinity, since $3.88 \mathrm{dS} \mathrm{m}^{-1}$ of electrical conductivity, dwarf plants grew without forming tubers and thus, are considered hypersensitive to this salinity.
\end{abstract}

Keywords: electrical conductivity, growth, osmotic stress, qualitative salinities, secondary tuber

\section{Introduction}

In Mexico potato crops cover an area of 72,000 ha and give an average yield under irrigation conditions of 30 $\mathrm{Mg} \mathrm{ha}^{-1}$ (Food and Agriculture Organization of the United Nations [FAO], 2008). Due to requirements of short photoperiods and to health, the commercial varieties are grown in semiarid areas whose soils have a greater or lesser degree problem of salinization, whether natural or induced by irrigation with saline waters of a concentration $>2.56 \mathrm{~g} \mathrm{~L}^{-1}$ (Sánchez, Camacho, Rodríguez, \& Ortega, 2012). These conditions affect $60 \%$ of the planted surface, and they are the reason why, in some areas, potatoes have stopped being grown, with low yields of about $14 \mathrm{Mg} \mathrm{ha}^{-1}$ obtained. They are comparable only to those obtained in rainy conditions by Mora, Rodríguez, Peña and Campos (2004), which implies environmental, economic and social damages. Important potato-farming soils in Mexico, such as in the Toluca valley, highlands of Nuevo León and the foothills of Laguna del Carmen in Tlaxcala, are affected by sulphate-hydrochloric, hydrochloric-sulphate and sulphate-sodium salinities, respectively. They are the result of soil geochemical formation factors that promote mobility, chemical interaction and the predominance of some ions over others in the soil solution, and that bring about specific formations and accumulations of soluble and toxic salts, such as $\mathrm{NaCl}, \mathrm{MgSO}_{4}$ and $\mathrm{NaHCO}_{3}$ (Ortega, Ramírez, Ontiveros, \& Rone, 1989). In this regard, Arinushkina cited by Kovda (1977), indicates that the sulphate-hydrochloric salinity is induced by a relation of $\frac{\mathrm{Cl}^{-1}}{\mathrm{SO}_{4}^{-2}} \approx 1.5$. Likewise, hydrochloric-sulphate salinity is a result of the ionic relation $\frac{\mathrm{Cl}^{-1}}{\mathrm{SO}_{4}^{-2}} \approx 0.6$, whereas sulphate-sodium salinity is given by a relation of 
$\frac{\mathrm{HCO}_{3}^{-1}}{\mathrm{Cl}^{-1}+\mathrm{SO}_{4}^{-2}} \approx 2.0$. According to Strogonov (1964) these salinities cause different effects in cultivated plants. The first salinity produces halophytism (succulent tissues). The second one tends to cause xerophytism (woody tissued and excessive root elongation) and the third one produces caustic and toxic effects in meristematic areas that atrophy the growth of glycophytes. Studies on the tolerance of potato plants to salinity stress and its effect on the growth and yield carried out under conditions of hydrochloride salinity (with a predominance of $\mathrm{NaCl}$ salt) by different scientists such as Bernstein (1964) and Rhaman, Islam, Hossain and Haider (2008), indicate that the potato is moderately sensitive to this salinity, because with an electrical conductivity (EC) of 3.0 to $6.0 \mathrm{dS}$ $\mathrm{m}^{-1}$ the potato reduced its yield by $50 \%$. Likewise, hydrochloride salinity reduces the growth and development of potato plants from their first stages, which decreased the filling and size of the tubers with low commercial value. This was also observed by Levy (1994) in potato cultivars that underwent an EC interval from 6.10 to $6.90 \mathrm{dS}$ $\mathrm{m}^{-1}$ of $\mathrm{NaCl}$ and $\mathrm{CaCl} \cdot 2 \mathrm{H}_{2} \mathrm{O}$ solutions. However, there are few studies on the behavior of potato plant growth in Mexico in a wider range of salinities. References include studies by Sánchez, et al. (2003) and Sánchez, Ortega, González, Camacho, and Kohashi (2008), who evaluated the emergence and biomass accumulation of tuber sprouts and $c v$. Alpha plants in diverse pure salts at EC from 0 to $15 \mathrm{dS} \mathrm{m}^{-1}$. The experimental evidence indicates that the increase in saline concentration induced a late tuberization, incomplete leaf development, a slow rate of tuber filling and secondary tuberization that formed small potatoes. The osmotic and toxic effects of $\mathrm{NaHCO}_{3}$ was more intense than that produced by the other experimental salts at EC $>3.88 \mathrm{dS} \mathrm{m}^{-1}$ that produced dwarf plants without formation of tubers. Recently, Sánchez and Ortega (2011) evaluated the emergence of sprouts of cv. Alpha tubers exposed to the sulphate-hydrochloric, hydrochloric sulphate and sulphate-sodium salinities at the concentrations above. They found that alkaline hydrolysis and toxicity caused by the sulphate-sodium salinity in the buds, inhibited their emergence at EC $>3.88 \mathrm{dS} \mathrm{m}^{-1}$. Likewise, they observed a multiple budding due to the loss of apical dominance induced by sulphate-hydrochloric and hydrochloric-sulphate salinities at EC from 8.11 to $10.0 \mathrm{dS} \mathrm{m}^{-1}$. Regardless of these investigations, there is no evidence of research on the effect of salinity in potato cv. Tollocan, a variety grown in Mexico for resistance to late blight (Aguilar, López, Núñez, \& Khalil, 2003). Hence our hypothesis considers that each type and level of salinity produce a differential adverse effect on growth and development of $S$. tuberosum cv. Tollocan and these are intensified as salinity increases. Consequently the biological and economic yields decline in prejudice of agricultural producer. The objective of this study was to evaluate the biomass accumulation in this potato variety under salinity conditions that simulate those prevailing in soils of some semi-arid valleys sown with potato in Mexico, and determine their tolerance to salinity conditions. The theoretical and practical implications of this study may be useful to potato growers, to make timely decisions on the use of irrigation water in a certain salt concentration, and in the application of hydrochemical methods such as salt lixiviation, establishment of artificial drainage or applying agricultural chemicals such as gypsum and elemental sulphur (Sánchez, Ortega, Sandoval, Viruel, \& Estrada, 2012) and breeding potato varieties for salt tolerance (Mudgal, Madaan, \& Mudgal, 2010). These alternative techniques suggest that it is possible to control this abiotic factor and generate less adverse conditions for growth and development of the potato variety analyzed.

\section{Materials and Methods}

Tubers of potato cv. Tollocan used as seed, were collected in the summer of 2010, from cultivars of Zinancatepec, State of Mexico, located at $19^{\circ} 17^{\prime}$ north and $99^{\circ} 44^{\prime} 38^{\prime \prime}$ west. This seed is grown widely in Toluca Valley, highlands of Nuevo Leon and foothills of Laguna del Carmen, Mexico, some of whose areas are affected by salinities analyzed in our study. The experiment was carried out between 10/10/2010 and 10/04/2011 in the greenhouse area of water and saline soils of Postgraduate College located in Montecillo, Mexico between $19^{\circ} 31^{\prime}$ 'north and $98^{\circ} 53^{\prime}$ ' east.

\subsection{Geochemistry Salt Potato Producing Areas to Which the Study Focuses}

\subsubsection{Toluca Valley}

$\left(19^{\circ} 17^{\prime}\right.$ north, $99^{\circ} 44^{\prime} 38^{\prime \prime}$ west) located at a height of 2680 meters, with a temperate climate and annual temperatures of 6 to $25^{\circ} \mathrm{C}$ is constituted by alluvial soils formed by weathering processes of andesitic and basaltic volcanic rocks and sediment deposition calcalkaline downstream (Moran, 1994). These rocks alternate with powerful depths of Quaternary volcanic ash rich in calcium and other nutrient ions. The climate and soil conditions favor the cultivation of potatoes, but soils are affected by anthropogenic salinization processes such as: a) irrigation with mineralized groundwater rich in $\mathrm{NaCl}, \mathrm{MgCl}_{2}, \mathrm{NaHCO}_{3}, \mathrm{Na}_{2} \mathrm{CO}_{3}, \mathrm{Na}_{2} \mathrm{SO}_{4}, \mathrm{Ca}\left(\mathrm{HCO}_{3}\right)_{2}$, $\mathrm{Mg}\left(\mathrm{HCO}_{3}\right)_{2}, \mathrm{CaCO}_{3}, \mathrm{MgCO}_{3}, \mathrm{CaSO}_{4}$ and $\mathrm{MgSO}_{4}$. The more soluble salts ascend to the surface by capillary action and are concentrated in the top soil. Consequently, the chloride salts predominate over sulphate salts, yielding a sulphate-hydrochloric salinity which osmotic and toxic effects reduce potato production. Other sources of salts in the area are the discharge of waste water rich in $\mathrm{NaHCO}_{3}$ and agricultural drainage to the natural waters of the hydrographic network. These are used for irrigation and increase in salt concentration (EC 
$\approx 800 \mu \mathrm{S} \mathrm{cm}^{-1}$ ) and sodium adsorption ratio $>2$, which favors processes of salinization and sodicity that increase the $\mathrm{pH}$, destroy soil structure and cause unavailability of nutrients like iron, zinc and manganese.

\subsubsection{Highlands of Nuevo León}

( $24^{\circ} 50^{\prime}$ north, $100^{\circ} 04^{\prime}$ 'west), located at 1550 meters above sea level, is part of the evaporate basin namely "Río Verde-Matehuala". It is a semi-arid area where evaporation exceeds precipitation, which favors the accumulation of salts in the upper soil thickness. It is an endorheic basin, formed by buried cretaceous seas. The weathering of metamorphic schists and Upper Jurassic sedimentary rocks such as gypsum and limestone, form soils gypsiferous that supports a xerophytic vegetation (López, 1993). Salts rise to the surface by capillary action and through irrigation water from deep wells loaded with $\mathrm{Na}_{2} \mathrm{SO}_{4}, \mathrm{NaCl}$ and $\mathrm{NaHCO}_{3}$ salts. The $\mathrm{CaSO}_{4}$ of soils, due to their low solubility precipitates. $\mathrm{Na}^{+1}$ from the soil solution displaces $\mathrm{Ca}^{2+}$ cation exchange complex, which raises the $\mathrm{pH}$ and promotes soil particle deflocculation. As a result a predominance of $\mathrm{Na}_{2} \mathrm{SO}_{4}$ over $\mathrm{NaCl}$ appears. Therefore the relationship $\mathrm{Cl}^{-} / \mathrm{SO}_{4}{ }^{-2} \approx 0.6$. The soils of the region have hydrochloric-sulphate salinity. The presence of large quantities of salt mirabilite $\left(\mathrm{Na}_{2} \mathrm{SO}_{4} \cdot 10 \mathrm{H}_{2} \mathrm{O}\right)$ originates unavailability of water for plants, which induces physiological drought.

\subsubsection{Laguna del Carmen, Tlaxcala ( $19^{\circ} 19^{\prime}$ north, $97^{\circ} 39^{\prime}$ west)}

It is located at an altitude of 2,380 meters above sea level. The climate is temperate dry with little rain in summer, rainfall is 500 to $600 \mathrm{~mm}$. Complies by colluvial soils formed from weathering of andesite-rich calco-sodic plagioclase, rhyolites, basalts and tuffs that cause a buildup of carbonate substrate. The endorheism favors natural processes of salt accumulation, but the area is also affected by rising groundwater due to the geothermal influence of Sierra de los Humeros (López, 1993). In addition to this natural process of salinization irrigation with groundwater rich in $\mathrm{Na}_{2} \mathrm{CO}_{3}$, favors sodification processes that generate adverse effects on potato cultivars.

\subsection{Methodologic Procedure}

In a greenhouse, $10 \mathrm{~kg}$ of perlite and a $2 \mathrm{~cm}$ thick cover of tezontle were placed in plastic experimental pots. The pots were then planted with $S$. tuberosum L. cv. Tollocan tubers, at a density of 2 propagules per pot spread 15 $\mathrm{cm}$ from each other. Two liters of saline solution were added to each pot. The treatments (independent experiments) used the sulphate-hydrochloric, hydrochloric-sulphate and sulphate-sodium salinities, plus a control $\left(\mathrm{C}_{0}\right)$ with distilled water and six saline concentrations of $1.13,2.48,3.84,5.19,6.40$ and $9.60 \mathrm{~g} \mathrm{~L}^{-1}$. These concentrations theoretically correspond to EC in solution of 1.77, 3.88, 6.0, 8.11, 10.0 and $15.0 \mathrm{dS} \mathrm{m}^{-1}$ and that according to Maas and Hoffman (1977) reduce the growth and yield of the plants sown in the order $0\left(\mathrm{C}_{1}\right), 25$ $\left(\mathrm{C}_{2}\right), 50\left(\mathrm{C}_{3}\right), 75\left(\mathrm{C}_{4}\right), 100\left(\mathrm{C}_{5}\right)$ and $150 \%\left(\mathrm{C}_{6}\right)$. The experimental design consisted of a random block model with three repetitions per treatment.

In the laboratory solutions of sulphate-hydrochloric, hydrochloric-sulphate and sulphate-sodium salinities were prepared based on anionic relations $\frac{\mathrm{Cl}^{-1}}{\mathrm{SO}_{4}^{-2}}=1.5, \frac{\mathrm{Cl}^{-1}}{\mathrm{SO}_{4}^{-2}}=0.6$ and $\frac{\mathrm{HCO}_{3}^{-1}}{\mathrm{Cl}^{-1}+\mathrm{SO}_{4}^{-2}}=2.0$, established by Arinushkina (Kovda, 1977). The first two salinities are a mixture of salts $\mathrm{NaCl}$ and $\mathrm{MgSO}_{4}$, whereas sulphate-sodium salinity results from the combination of $\mathrm{MgCl}_{2}, \mathrm{Na}_{2} \mathrm{SO}_{4}$ and $\mathrm{NaHCO}_{3}$. The $\mathrm{pH}$ of the solutions were determined along with their electric conductivity EC $\left(\mathrm{dS} \mathrm{m}^{-1}\right)$ using a Hanna ${ }^{\circledR} \mathrm{HI} 98129$ multiparameter. The osmotic potential $\Psi \pi$ (MPa) was evaluated with a Vapro Wescor 5520 osmometer. The flasks containing the saline solutions were added to a 40-40-20 formula of nutrient solution (Steiner, 1984). Once prepared, they were irrigated onto the planted pots, replacing the water consumed by evapotranspiration after every 3rd day in order to keep experimental units at field capacity and at a constant weight. The temperatures registered in the greenhouse were 16 to $32^{\circ} \mathrm{C}$. The study covered the vegetative, initiation, growth and maturity stages of the tuber. During that time a phytosanitary control was carried out in order to protect the plants from late blight (Phytophtora infestans) and, for this, they were sprayed with the Ridomil Gold Mz 68 WP fungicide. To evaluate growth, one bud was left on each tuber. Each plant was composed of a main stem which produced two plants per pot. Three determinations were made for plant height and number of leaves per plant at 20,50 and 80 days after emergence. Plants were sowed separating aerial and underground organs. The number and diameter of secondary tubers were evaluated for every plant, as well as the root length and the fresh weight of each of the parts, resulting in the recording of the average weight of six plants per treatment. The growth variables evaluated were: the number of mature leaves, stem length $(\mathrm{cm})$ from the surface of the soil to the apex of the stem; the rate of the stem length increase using the formula: $T I L=\left\lfloor\frac{\left(L T_{2}-L T_{1}\right)}{\left(T_{2}-T_{1}\right)}\right\rfloor$, where: $\mathrm{LT}_{2}$ and $\mathrm{LT}_{1}$ : main stem length at the end and the beginning of a certain time period and $T_{2}$ and $T_{1}$ : final and initial time of the given period. Root length $(\mathrm{cm})$ was measured from the axillary bud of the mother tuber to the furthest apex. Likewise the foliar area per plant was determined in leaves of the middle third with a Licor LI-3100 area integrator, using linear regression between the dry weight of the sheets and the area of each sheet. The biomass accumulation was determined by adding the dry 
weight $(\mathrm{g})$ of the root, tubers and aerial section of the plants, and the proportional biomass accumulation was obtained by dividing the dry weight of each organ by the total dry weight of the plant. In addition, the foliar area index was evaluated (Watson, 1947) based on the formula: $F A I=\frac{\text { FoliarArea per plant }}{\text { Area of land occupied by the plant }}$, where: $\mathrm{FAI}=$ Foliar Area Index per plant, for which was considered the area of land taken up by the plant, as well as the duration of foliar area in days with the formula: $D F A=\frac{\left[F A I_{1}+F A I_{2}\right] \cdot\left[T_{2}-T_{1}\right]}{2}$, where: $\mathrm{FAI}_{1}$ e $\mathrm{FAI}_{2}$ : Foliar Area Index determined in moments $\mathrm{T}_{1}$ and $\mathrm{T}_{2}$ after emergence (Hunt, 1982). Net photosynthesis was determined during the tuber growing stage, in lateral leaflets of the fifth mature leaf, through an infrared gas analyzer (IRGA) LICOR Inc. ${ }^{\circledR}$ model LI6200. A mathematical model was calibrated for the prediction of the total dry weight of plants (DWP) based on the osmotic potential $(\Psi \pi)$ of the solutions using the equation: $\mathrm{Y}=\mathrm{A}+\mathrm{Bx}$, where $\mathrm{Y}$ : total dry weight of the plant (g), A: origin ordinate, B: slope of the line or number of units that the DWP increases or decreases per unit of negative increase of the $\Psi \pi$ of the saline solution, and $\mathrm{x}: \Psi \pi$ of the saline solution (MPa). Finally, the level of tolerance of the potato plants cv. Tollocan to each of the salinities used was also determined. For this purpose the threshold salinity $\left(\mathrm{S}_{\mathrm{t}}\right)$ was considered. The threshold salinity is the maximum level of average salinity in the rhizosphere that can be tolerated by the potato plants under conditions of hydrochloride salinity without limiting their growth. Therefore biological yield (BY) continues to be at $100 \%$, and equivalent to an EC of soil saturation extract about $2 \mathrm{dS} \mathrm{m}^{-1}$ (Bernstein, 1964), and the percentage of yield reduction per unit of increase of the $\mathrm{S}_{\mathrm{t}}$. The hypothetical reduction of the BY was predicted using the equations by Maas and Hoffman (1977), Y=100-b国Cs-A and $b=\frac{100}{E C_{S} \text { for } Y=0 \%-S_{u}}$, where $\mathrm{Y}$ : yield; A: threshold salinity $\left(\mathrm{dS} \mathrm{m}^{-1}\right), \mathrm{b}$ : percentage decrease of yield per unit of saline increase, $\mathrm{EC}_{\mathrm{s}}$ : electrical conductivity of the saline solution. The linear regression and variance to determine significant differences with $\mathrm{P}=0.05$ were carried out using the statistical analysis system SAS (2006).

\section{Results and Discussion}

\subsection{Vegetative Growth of Aerial Organs}

The formation of leaves per plant in the vegetative stage (20 days after emergence) displayed quantitative differences according to the type of salinity and EC level (Table 1). In the treatments with sulphate-hydrochloric and hydrochloric-sulphate salinities, an average of 9 and 11 photosynthetically active leaves respectively were formed in the EC interval $\left(1.77\right.$ to $\left.8.11 \mathrm{dS} \mathrm{m}^{-1}\right)$. At higher concentrations, the number of leaves per plant was reduced to 7 . This behavior was attributed to an initial stimulus of nutritional type, produced by mineral salts to induce the growth of plant organs up to a certain EC. After which growth is reduced by the osmotic and toxic effect of these salinities. This phenomenon was observed by Strogonov (1964) in tomato plants (Lycopersicon esculentum L.) exposed to such salinities, and later described by Levy (1994) in potato plants grown in hydrochloride salinity conditions. On the other hand, plants grown under conditions of sulphate-sodium salinity formed eight photosynthetically active leaves, but only to an EC of $1.77 \mathrm{dS} \mathrm{m}^{-1}$. After that, the number of leaves dropped notably. This relates to the toxic and alkaline effect produced by this salinity in mid-growth which damages meristematic tissues that promote sprouting and limits the carbohydrate and starch supplies from the mother tuber to the aerial organs that delay the rates of foliar expansion. Similar behavior was observed by Sanchez and Ortega (2011) in tuber sprouts cv. Alpha irrigated with sodium bicarbonate solutions. From a physiological point of view, this difference indicates that the cv. Tollocan plants that formed 9 and 11 leaves at this stage induced the formation of stolons, whereas those that did not limited tuberization, as noted by Moorby \& Milthorpe (1983). The most drastic inhibitory effect was produced by the sulphate-sodium salinity at EC $>$ $3.88 \mathrm{dS} \mathrm{m}^{-1}$. Subsequently during the initial stage of tuber, potato plants displayed a delay in the formation of leaves, since in three salinities and the control up to 14 photosynthetically active leaves were formed in the EC interval (1.77 to $3.88 \mathrm{dS} \mathrm{m}^{-1}$ ). However, according to Milthorpe (1993), this number of leaves must be formed approximately 40 days after emergence. The delay is related to the scarce FAI between 1.0 and 1.5 which is lower than the index $\sim 2.0$ required to induce the appearance of tubers (Khurana \& McLaren, 1982; De la Casa, Ovando, Bressanini, Rodríguez, \& Martínez, 2007). However, there are exceptions since in hydrochloric-sulphate salinity conditions at EC of $3.88 \mathrm{dS} \mathrm{m}^{-1}$ FAI was $>2.0$. The lowest number of leaves and FAI per plant were registered under conditions of sulphate-sodium salinity at EC $>6.0 \mathrm{dS} \mathrm{m}^{-1}$ which displayed a significant difference $(\mathrm{P}=0.05)$ with other treatments. According to Poljakoff and Lerner (1994), salinity affects the initial development of the foliar system of the glycophytes, and in the case of potato plants, this generates a low rate of formation and filling of tubers, consequently producing small potatoes as reported by Nadler \& Heuer (1998). During the growth of the tuber ( 80 days after emergence) the potato plants subjected to the control and sulphate-hydrochloric and hydrochloric-sulphate salinities averaged 18 leaves, with no significant difference between these treatments and their concentrations. This foliar development is insufficient for the promotion of tuber growth, since according to Milthorpe (1993), an adequate foliar formation for this stage is $\sim 22$ leaves per 
plant. On the other hand, those grown in sulphate-sodium conditions displayed the least foliar development since they formed 17 leaves at $\mathrm{EC}$ of $1.77 \mathrm{dS} \mathrm{m}^{-1}$, after which the number of leaves dropped significantly. The limited foliar expansion due to osmotic stress produced by the salinity, leads a water deficit (physiological drought) in the foliar tissues that inhibit cellular growth by plasmolysis, an effect can be reversible or permanent, depending on the intensity and duration of the stress, and this in extreme cases can cause caustic effects and death of the plant tissues (Sánchez \& Ortega, 2011). This reduction in foliar growth results in a lower translocation of photo assimilates to the tubers that will consequently reduce growth. The reduction of the foliar area was drastic under conditions of sulphate-sodium salinity, in which dwarf plants grew with a microfile foliar system. A similar phenomenon was observed by Sanchez et al. (2008) in S. tuberosum L. cv. Alpha subject to the same salt conditions, so that asserted this is a behavior of haloxeric adaptation to this type of salinity.

\subsubsection{Osmotic Effect in the Leaves and Net Photosynthesis}

We must not elude the osmotic effect produced by salinities that induced water stress in the leaves of potato plants, especially to EC $>6.0 \mathrm{dS} \mathrm{m}^{-1}$ in the case of sulphate-hydrochloric and hydrochloric-sulphate salinities, and $>3.88 \mathrm{dS} \mathrm{m}^{-1}$ in sulphate-sodium salinity (Table 2), which limited foliar growth and tuberization. In this respect, Moorby and Milthorpe (1983) point out that water deficits $>-0.5 \mathrm{MPa}$ in potato leaves reduce foliar expansion and affect photosynthetic production. The values of net photosynthesis measured 50 days after emergence in potato plants cv. Tollocan, are slightly higher than those reported by Prange, McRae, Midmore, \& Peng (1990), for potato plants subjected to drought conditions in the order of $6.22 \mathrm{~mol} \mathrm{CO}_{2} \mathrm{~m}^{2} \mathrm{~s}^{-1}$, which recorded leaf water potential of -0.8 to $-1.0 \mathrm{MPa}$, very similar to those obtained in the present investigation. This indicates that the salinities had little effect on the net photosynthetic production and that this was not limiting tuberization. However, the salt effect decreased translocation of photo assimilates from leaves to tubers growing and transformed source organs into storage organs. This is the main reason why minitubers formed. Strogonov (1964) observed this behavior in many gliycophytes as a mechanism to counteract salt stress. In essence, the three salinities decreased photosynthesis under increased salt levels (Table 2) which was accompanied by a lowering of the values of stomatal conductance and transpiration of leaves, phenomenon according to $\mathrm{Ku}$, Edwards, and Tanner (1977), is highly correlated with stomatal closure. Meanwhile Strogonov (1964) indicates that water stress produced by these salinities, besides increasing the stomatal resistance to $\mathrm{CO}_{2}$ fixation, inhibits both photochemical reactions as foliar cell growth which is associated with a reduced number of chloroplasts. This explains the poor growth of the leaf system of potato plants to high levels of EC, especially sulphate -sodium salinity to EC $>6.0 \mathrm{dS} \mathrm{m}^{-1}$, which had the lowest photosynthetic production. Statistical inference indicates that in the three saline treatments EC level of $15 \mathrm{dS} \mathrm{m}^{-1}$, showed significance because potato plants markedly decreased net photosynthesis. Likewise, the plants were also subjected to water stress produced by excess evaporation between irrigations caused by greenhouse temperatures above $30{ }^{\circ} \mathrm{C}$ which influenced the foliar growth inhibition. In this regard, Prange et al. (1990) point out that thermal and water stress delay the foliar development of the potato plant.

\subsection{Leaf Development during the Growth of the Tuber and Foliar Senescense}

In the tuber growing stage ( 80 days after emergence) the potato plants subjected to the control and sulphate-hydrochloric and hydrochloric-sulphate salinities averaged 19 leaves with no significant difference between these treatments and their concentrations. This foliar development is insufficient for the promotion of tuber growth since according to Milthorpe (1993), an adequate foliar formation for this stage is $\sim 22$ leaves per plant. On the other hand, those grown in sulphate-sodium conditions displayed the least foliar development since they formed 17 leaves at $\mathrm{EC}$ of $1.77 \mathrm{dS} \mathrm{m}^{-1}$, after which the number of leaves dropped significantly. The limited foliar expansion due to osmotic stress produced by the salinity leads to a water deficit (physiological drought) in the foliar tissues that inhibit cellular growth by plasmolysis, an effect which can be reversible or permanent depending on the intensity and duration of the stress, and that in extreme cases can cause caustic effects and death of the plant tissues (Strogonov, 1964). This reduction in foliar growth results in a lower translocation of photo assimilates to the tubers that will consequently result in little growth. The reduction of the foliar area was drastic under conditions of sulphate-sodium salinity. The formation of microfile foliar system in potato plants was also noted in concentrations of salt $\mathrm{NaHCO}_{3}$ above $10 \mathrm{dS} \mathrm{m}^{-1}$ by Sánchez et al. (2003). Likewise the phenomenon was observed by Barahmi and Razmjoo (2012) in sesame (Sesamum indicum L.) cultivars growth in levels of salinity greater than $12.05 \mathrm{dS} \mathrm{m}^{-1}$. On the other hand potato plants that underwent sulphate-hydrochloric and hydrochloric-sulphate salinities in all their EC, displayed deteriorated leaves $\sim 75$ days after emergence, behavior that was premature considering the life cycle of intermediate varieties that is 90 days (Aguilar et al., 2003). Plants grown in conditions of sulphate-sodium salinities underwent foliar deterioration 100 days after emergence and thus the greatest foliar delay. According to Pyung, Kim, and Nam (2007) premature 
leaf senescence is a natural behavior of glycophytes to heat, water or saline stress. In the present study salinity stress caused the alteration in the time of sprout emergence. This in turn prolonged the period of foliar formation and caused the deterioration and death of foliar tissue in the stage of tuber growth which, when shortened and not receiving the necessary photo assimilates, limited the development and expansion of tubers. In this respect Wolf (1993), indicate that foliar senescence reduces photosynthate transport and storage into the potato plants tubers and argued that the potato plants with underdeveloped foliar systems form small tubers.

\subsection{Stem Length}

In sulphate-hydrochloric and hydrochloric-sulphate salinities, the potato plants increased their stem length 20 to 50 days after emergence with EC increments in saline solutions from 0 to $15.0 \mathrm{dS} \mathrm{m}^{-1}$, which is attributed to a rapid and unsustained growth observed in young bean (Phaseolus vulgaris L.), tomato and cotton (Gossipium hirsutum L.) plants to avoid saline stress in a seasonal manner. Poljakoff and Lerner (1994) and Barahmi and Razmjoo (2012) consider this response to be a physiological mechanism of glycophytes to tolerate saline conditions. On the other hand, potato plants exposed to sulphate-sodium salinity displayed this growth up to an EC of $3.88 \mathrm{dS} \mathrm{m}^{-1}$. At higher saline levels $\left(6.0\right.$ to $\left.15.0 \mathrm{dS} \mathrm{m}^{-1}\right)$ they reduced their size noticeably, thus presenting statistical significance over the other treatments wit $\mathrm{P}=0.05$. Likewise, the $\mathrm{EC}$ of $15 \mathrm{dS} \mathrm{m}^{-1}$ showed significance in the three salinities as shown in Table 3. Between 50 and 80 days after emergence, the tendency to grow continued, although the rate of increase in length (RIL) in all three saline treatments are lower than those reported by Mora et al. (2004) for cv. Alpha potato plants in rainy conditions $(0.79 \mathrm{~cm}$ per day with a stem length of $45 \mathrm{~cm}$ ). This indicates that these salinities reduced the final growth of the stem. The growth inhibition caused by these salinities from the initial stages and the formation of smaller than normal plants, with scarce leaves and reduced foliar area, influenced growth inhibition and the filling of tubers. Damage was most severe under sulphate-sodium salinity conditions.

\subsection{Root Length}

In natural conditions, the root growth of potato plants decreases 40 to 50 days after emergence (stage of expansion and maturity of the tuber), and this has to do with the translocation of assimilates of the root towards the tubers in formation (Rousselle \& Robert, 1996; Iwama, 2008). In this study, the reduction in the percentage of the length of the root in regard to the control is attributed to the osmotic and toxic stress induced by each one of the salinities primordially in EC $>3.88 \mathrm{dS} \mathrm{m}^{-1}$. This reduction presented the following order: sulphate-sodium salinity $(24.72 \%)>$ hydrochloric-sulphate salinity $=$ sulphate-hydrochloric salinity $(6.99 \%)$. The differential effect produced by each salinity was evident, since among the root caps in potato plants exposed to the last two salinities, a slight caustic effect was noticed in the apical meristem. The effect was greater in the roots exposed to the sulphate-sodium salinity. In this case the sodium sulphate treatment and EC of $15 \mathrm{dS} \mathrm{m}^{-1}$, showed significant difference with $\mathrm{P}=0.05$. They displayed necrosis, a sign that according to Sánchez et al. (2003) is caused by severe cellular dehydration, along with alkaline hydrolysis and the inhibition of the reductase nitrate, which affect the production of protoplasm, cell division and the elongation of meristematic cells. Experiments carried out by Strogonov (1964) with cotton plants, alfalfa (Medicago sativum L.) and bermuda grass (Cynodon dactylon $L$.) in conditions of hydrochloride salinity, reveal that concentrations $>6 \mathrm{~g} \mathrm{~L}^{-1}$ of $\mathrm{NaCl}$ in the growth medium, strongly inhibited the area of cell division and the root elongation. The root entered a state of stillness and its growth decreased.

Similar observations were reported by Nadler and Heuer (1998) in potato plants exposed to $100 \mathrm{mM} \mathrm{NaCl}$ solutions. Basically, the lower root elongation reduced the volume of soil explored and consequently resulted in a lower availability and absorption of water and nutrients which caused the reduction of plant growth. In this study, the saline concentration that favoured root growth in comparison to the control was $1.13 \mathrm{~g} \mathrm{~L}^{-1}$ in the sulphate-hydrochloric salinity, indicating that the root of the potato cv. Tollocan is intolerant to experimental salinities at high concentrations and is therefore sensitive to saline stress, especially in the tuber growing stage. 
Table 1. Effects of salinity and concentration in the foliar growth of $c v$. Tollocan potato plants

\begin{tabular}{|c|c|c|c|c|c|c|c|c|}
\hline \multirow{3}{*}{ Treatment } & \multirow[t]{2}{*}{$\mathrm{EC}$} & \multicolumn{3}{|c|}{ Number of leafs (DAE) ${ }^{8}$} & \multicolumn{2}{|c|}{ Foliar area $\left(\mathrm{cm}^{2}\right)$} & \multicolumn{2}{|c|}{ Foliar Area Index } \\
\hline & & \multirow{2}{*}{$\begin{array}{l}20 \\
4\end{array}$} & \multirow{2}{*}{$\begin{array}{c}50 \\
\supset\end{array}$} & \multirow{2}{*}{$\begin{array}{c}80 \\
0\end{array}$} & \multirow{2}{*}{${ }_{8}^{50 \mathrm{DAE}}$} & \multirow{2}{*}{80} & \multirow{2}{*}{$\begin{array}{l}\text { FAI } 50 \\
\text { DAE }\end{array}$} & \multirow{2}{*}{$\begin{array}{l}\text { FAI } 80 \\
\text { DAE }\end{array}$} \\
\hline & $\mathrm{dS} \mathrm{m}^{-1}$ & & & & & & & \\
\hline Control & 0 & $10^{\mathrm{a}}$ & $13^{\mathrm{a}}$ & $19^{a}$ & 31.52 & $25.20^{\mathrm{a}}$ & 1.6 & $1.20^{\mathrm{a}}$ \\
\hline Sulphate- hydrochloric salinity & 1.77 & $10^{\mathrm{a}}$ & $14^{\mathrm{a}}$ & $19^{\mathrm{a}}$ & 32 & $25.00^{\mathrm{a}}$ & 1.75 & $1.25^{\mathrm{a}}$ \\
\hline \multirow[t]{5}{*}{$\mathrm{A}^{1}, \mathrm{~A}^{2,} \mathrm{~A}^{3}, \mathrm{~A}^{\prime}$} & 3.88 & $9^{a}$ & $14^{\mathrm{a}}$ & $19^{\mathrm{a}}$ & 31.05 & $25.53^{\mathrm{a}}$ & 1.7 & $1.20^{\mathrm{a}}$ \\
\hline & 6 & $9^{\mathrm{a}}$ & $14^{\mathrm{a}}$ & $19^{\mathrm{a}}$ & 27.5 & $23.00^{\mathrm{a}}$ & 1.55 & $1.10^{\mathrm{a}}$ \\
\hline & 8.11 & $8^{\text {ab }}$ & $13^{\text {ab }}$ & $18^{\mathrm{ab}}$ & 24.2 & $22.44^{\mathrm{ab}}$ & 1.35 & $1.08^{\mathrm{a}}$ \\
\hline & 10 & $7^{\mathrm{ab}}$ & $13^{\text {ab }}$ & $16^{\mathrm{b}^{*}}$ & 23.5 & $21.74^{\mathrm{b}}$ & 1.34 & $1.05^{\mathrm{ab}}$ \\
\hline & 15 & $5^{b^{*}}$ & $12^{b^{*}}$ & $16^{\mathrm{b}^{*}}$ & 22 & $20.44^{\mathrm{b}^{*}}$ & 1.1 & $0.90^{\mathrm{b}^{*}}$ \\
\hline Hydrochloric- sulphate salinity & 1.77 & $10^{\mathrm{a}}$ & $14^{\mathrm{a}}$ & $19^{\mathrm{a}}$ & 36 & $26.60^{\mathrm{a}}$ & 2 & $1.20^{\mathrm{a}}$ \\
\hline \multirow[t]{5}{*}{$\mathrm{A}^{1}, \mathrm{~A}^{2}, \mathrm{~A}^{3}, \mathrm{~A}^{\prime}$} & 3.88 & $9^{a}$ & $14^{\mathrm{a}}$ & $19^{\mathrm{a}}$ & 36.55 & $26.00^{\mathrm{a}}$ & 1.95 & $1.25^{\mathrm{a}}$ \\
\hline & 6 & $9^{\mathrm{ab}}$ & $13^{\text {ab }}$ & $19^{\mathrm{a}}$ & 32.07 & $23.75^{a b}$ & 1.86 & $1.18^{\mathrm{a}}$ \\
\hline & 8.11 & $9^{\text {ab }}$ & $13^{\text {ab }}$ & $18^{\mathrm{ab}}$ & 31.33 & $23.60^{\mathrm{ab}}$ & 1.6 & $1.15^{\mathrm{a}}$ \\
\hline & 10 & $7^{\text {ab }}$ & $12^{\mathrm{ab}}$ & $17^{\mathrm{ab}}$ & 28.05 & $24.00^{\mathrm{ab}}$ & 1.3 & $1.05^{\mathrm{ab}}$ \\
\hline & 15 & $5^{b^{*}}$ & $11^{\mathrm{b}^{*}}$ & $16^{\mathrm{b}^{*}}$ & 20 & $20.10^{\mathrm{b}^{\pi}}$ & 1.15 & $1.00^{\mathrm{b}}$ \\
\hline Sulfphate-sodium salinity & 1.77 & $8^{a}$ & $13^{\mathrm{a}}$ & $16^{\mathrm{a}}$ & 22 & $20.34^{\mathrm{a}}$ & 1.2 & $1.18^{\mathrm{a}}$ \\
\hline \multirow[t]{5}{*}{$\mathrm{B}^{1^{*}}, \mathrm{~A}^{2}, \mathrm{~B}^{3^{*}}, \mathrm{~B}^{\prime}$} & 3.88 & $7^{\mathrm{a}}$ & $12^{\mathrm{a}}$ & $15^{\mathrm{a}}$ & 26.55 & $21.37^{\mathrm{a}}$ & 1.4 & $1.05^{\mathrm{a}}$ \\
\hline & 6 & $2^{\mathrm{ab}}$ & $11^{\mathrm{a}}$ & $12^{\mathrm{ab}}$ & 20.93 & $17.15^{\mathrm{ab}}$ & 1.1 & $0.98^{\mathrm{ab}}$ \\
\hline & 8.11 & $2^{\mathrm{ab}}$ & $10^{\text {ab }}$ & $12^{\mathrm{ab}}$ & 18.9 & $16.77^{\mathrm{ab}}$ & 1 & $0.85^{\mathrm{ab}}$ \\
\hline & 10 & $2^{\mathrm{ab}}$ & $8^{\mathrm{ab}}$ & $10^{b^{\pi}}$ & 20 & $15.00^{\mathrm{ab}}$ & 1 & $0.70^{\mathrm{ab}}$ \\
\hline & 15 & $1^{\mathrm{b}^{*}}$ & $6^{\mathrm{b}^{\mathrm{x}}}$ & $9^{b^{*}}$ & 16.85 & $7.00^{\mathrm{b}^{*}}$ & 0.85 & $0.25^{\mathrm{b}^{*}}$ \\
\hline
\end{tabular}

${ }^{\S} \mathrm{DAE}=$ Days after emergence.

$\mathrm{A}, \mathrm{B}=$ test of averages between types of salinity and the variables: ${ }^{1}$ No. of leaves $20 \mathrm{DAE}(\mathrm{P}>\mathrm{F}=0.0001),{ }^{2}$ No. of leaves $50 \mathrm{DAE}(\mathrm{P}>\mathrm{F}=0.0001),{ }^{3}$ No. of leaves $80 \mathrm{DAE}(\mathrm{P}>\mathrm{F}=0.0001)$ and ${ }^{7}$ foliar area $80 \mathrm{DAE}(\mathrm{P}>\mathrm{F}=$ 0.001). a, b, ab: Test of averages between EC levels and variables: ${ }^{4}$ No. of leaves $20 \mathrm{DAE}(\mathrm{P}>\mathrm{F}=0.0001) ;{ }^{5} \mathrm{No}$. of leaves $50 \mathrm{DAE}(\mathrm{Pr}>\mathrm{F}=0.0002),{ }^{6}$ No. of leaves $80 \mathrm{DAE}(\mathrm{P}>\mathrm{F}=0.004)$ and ${ }^{8}$ foliar area $80 \mathrm{DAE}(\mathrm{P}>\mathrm{F}=$ $0.8336)$. Same alphabetica $(\mathrm{a}),(\mathrm{ab})$ indicates no significant difference. $(*)$ Statistical significance on Duncan-test $(\mathrm{P}=0.05)$.

Table 2. $\Psi \pi$ of saline solutions, $\Psi_{\mathrm{h}}$ in the fifth leaf and net photosynthesis 50 DAE of potato plants cv. Tollocan

\begin{tabular}{|c|c|c|c|c|c|c|c|c|c|}
\hline Treatment & $\begin{array}{l}\mathrm{EC} \\
\mathrm{dS} \\
\mathrm{m}^{-1}\end{array}$ & $\begin{array}{l}\Psi \pi \\
\text { solution } \\
\mathrm{MPa}\end{array}$ & $\begin{array}{ll}\Psi_{\mathrm{h}} & \text { in } \\
\text { leafs } & \\
\mathrm{MPa} & \\
2 & \end{array}$ & $\begin{array}{l}\mathrm{FN} \\
\mu \mathrm{mol}^{2} \mathrm{~s}^{-1} \\
\mathrm{~m}_{4}\end{array}$ & $\begin{array}{l}\mathrm{TR} \\
\mathrm{umol}_{\mathrm{m}^{2} \mathrm{~s}^{-1}}\end{array}$ & $\mathrm{H}_{2} \mathrm{O}$ & $\begin{array}{l}\mathrm{RS} \\
\mu \mathrm{mol}^{2} \mathrm{~m}^{-1}\end{array}$ & $\mathrm{H}_{2} \mathrm{O}$ & $\begin{array}{l}\mathrm{CS} \\
\mathrm{cm}^{3} \\
\mathrm{~s}^{-1}\end{array}$ \\
\hline Control & 0.00 & 0.00 & $-0.30 \mathrm{a}$ & 16.30 & 0.53 & & 1.34 & & 8.48 \\
\hline \multirow{6}{*}{$\begin{array}{l}\text { Sulphate } \\
\text {-hydrochloric } \\
\mathrm{A}^{1} \mathrm{~A}^{3}\end{array}$} & 1.77 & -0.13 & $-0.54^{a}$ & $11.83^{\mathrm{a}}$ & 0.38 & & 0.99 & & 7.24 \\
\hline & 3.88 & -0.17 & $-0.38^{a}$ & $10.96^{\mathrm{ab}}$ & 0.25 & & 0.63 & & 7.47 \\
\hline & 6.00 & -0.22 & $-1.02^{a b}$ & $10.88^{a b}$ & 0.35 & & 0.80 & & 7.14 \\
\hline & 8.11 & -0.27 & $-1.16^{\mathrm{ab}}$ & $9.23^{\mathrm{ab}}$ & 0.31 & & 0.79 & & 7.18 \\
\hline & 10.0 & -0.33 & $-0.42^{a b}$ & $9.98^{\mathrm{ab}}$ & 0.33 & & 0.85 & & 7.03 \\
\hline & 15.0 & -0.52 & $-1.18^{b^{*}}$ & $5.67^{b^{*}}$ & 0.25 & & 0.63 & & 5.36 \\
\hline & 1.77 & -0.14 & $-0.54^{\mathrm{a}}$ & $12.29^{\mathrm{a}}$ & 0.52 & & 1.32 & & 8.58 \\
\hline \multirow{5}{*}{$\mathrm{A}^{1} \mathrm{~A}^{3}$} & 3.88 & -0.15 & $-0.38^{a}$ & $10.29^{a b}$ & 0.50 & & 1.12 & & 7.57 \\
\hline & 6.00 & -0.18 & $-0.96^{\mathrm{ab}}$ & $10.20^{\mathrm{ab}}$ & 0.44 & & 1.10 & & 7.31 \\
\hline & 8.11 & -0.22 & $-0.42^{a b}$ & $9.18^{\mathrm{ab}}$ & 0.39 & & 1.02 & & 7.06 \\
\hline & 10.0 & -0.27 & $-0.90^{a b}$ & $10.13^{a b}$ & 0.37 & & 0.97 & & 7.04 \\
\hline & 15.0 & -0.40 & $-1.16^{b^{*}}$ & $7.47^{b^{*}}$ & 0.33 & & 0.85 & & 5.34 \\
\hline Sulphate sodium & 1.77 & -0.15 & $-0.40^{\mathrm{a}}$ & $11.90^{\mathrm{a}}$ & 0.64 & & 1.00 & & 7.45 \\
\hline $\mathrm{A}^{1} \mathrm{~B}^{3 *}$ & 3.88 & -0.19 & $-0.80^{a}$ & $8.78^{a b}$ & 0.55 & & 1.05 & & 7.48 \\
\hline
\end{tabular}




\begin{tabular}{lllllll}
\hline 6.00 & -0.22 & $-0.72^{\mathrm{ab}}$ & $7.69^{\mathrm{ab}}$ & 0.49 & 1.12 & 7.15 \\
8.11 & -0.27 & $-0.90^{\mathrm{ab}}$ & $6.57^{\mathrm{ab}}$ & 0.41 & 1.15 & 6.23 \\
10.0 & -0.30 & $-1.10^{\mathrm{ab}}$ & $6.55^{\mathrm{ab}}$ & 0.40 & 1.39 & 5.19 \\
15.0 & -0.60 & $-1.24^{\mathrm{b}^{*}}$ & $5.12^{\mathrm{b}^{*}}$ & 0.40 & 1.62 & 5.00 \\
\hline
\end{tabular}

$\S \Psi \pi=$ osmotic potential of saline solutions. $\Psi_{\mathrm{h}}=$ water potential of the leaves.

$\mathrm{A}, \mathrm{B}=$ test of averages between types of salinity and the variable: ${ }^{1}$ water potential in leaves $(\mathrm{P}>\mathrm{F}=0.0009),{ }^{3}$ net photosynthesis in the fifth leaf $(\mathrm{P}>\mathrm{F}=0.0001)$. $\mathrm{a}, \mathrm{b}=$ Test of averages between EC levels for the variable: ${ }^{2}$ water potential in leaves $(\mathrm{P}>\mathrm{F}=0.0001) .{ }^{4}$ Net photosynthesis in the fifth leaf $(\mathrm{P}>\mathrm{F}=0.0001)$.

Same alphabetica (a), (ab) indicates no significant difference. $(*)$ Statistical significance on Duncan-test $(\mathrm{P}=$ $0.05)$.

Table 3. Plant height and final elongation of the root, in each type of salinity and EC level

\begin{tabular}{|c|c|c|c|c|c|c|c|}
\hline \multirow[t]{2}{*}{ Salinity } & \multirow[t]{2}{*}{ 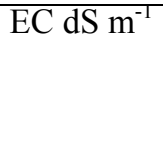 } & \multicolumn{3}{|c|}{ Plant height } & \multirow{2}{*}{$\begin{array}{l}\text { RIL } \\
\text { Period (20 } \\
\text { a } 50 \text { DAE) } \\
\mathrm{cm} \mathrm{d}^{-1}\end{array}$} & \multirow{2}{*}{$\begin{array}{l}\text { RIL } \\
\text { Period (50 } \\
\text { a } 80 \text { DAE }) \\
\mathrm{cm} \mathrm{d}^{-1}\end{array}$} & \multirow{2}{*}{$\begin{array}{l}\text { Root } \\
\text { lenghtcm }\end{array}$} \\
\hline & & $20 \mathrm{DDE}^{8}$ & $50 \mathrm{DDE}$ & $80 \mathrm{DDE}$ & & & \\
\hline Control & 0.00 & 14.00 & 22.45 & $40.00^{a / 3}$ & 0.25 & 0.60 & $35.00^{\mathrm{a} / 4}$ \\
\hline \multirow{6}{*}{$\begin{array}{l}\text { Sulphate-hy } \\
\text { drochloric } \\
\mathrm{A}^{1}, \mathrm{~A}^{2}\end{array}$} & 1.77 & 16.00 & 24.00 & $40.00^{\mathrm{a}}$ & 0.40 & 0.44 & $32.50^{\mathrm{a}}$ \\
\hline & 3.88 & 12.60 & 25.00 & $38.00^{\mathrm{a}}$ & 0.40 & 0.47 & $30.00^{\mathrm{a}}$ \\
\hline & 6.00 & 11.10 & 24.50 & $37.00^{\mathrm{a}}$ & 0.42 & 0.47 & $28.00^{\mathrm{a}}$ \\
\hline & 8.11 & 9.25 & 22.30 & $36.50^{\mathrm{ab}}$ & 0.45 & 0.49 & $26.30^{\mathrm{ab}}$ \\
\hline & 10.00 & 8.00 & 21.70 & $36.00^{a b}$ & 0.46 & 0.48 & $26.30^{\mathrm{ab}}$ \\
\hline & 15.00 & 6.40 & 20.00 & $30.50^{b^{*}}$ & 0.47 & 0.50 & $25.00^{b^{*}}$ \\
\hline \multirow{6}{*}{$\begin{array}{l}\text { Hydrochlori } \\
\text { c-sulphate } \\
\mathrm{A}^{1}, \mathrm{~A}^{2}\end{array}$} & 1.77 & 17.60 & 27.60 & $40.00^{\mathrm{a}}$ & 0.47 & 0.51 & $30.65^{\mathrm{a}}$ \\
\hline & 3.88 & 13.45 & 26.00 & $39.00^{\mathrm{a}}$ & 0.42 & 0.51 & $30.05^{\mathrm{a}}$ \\
\hline & 6.00 & 12.75 & 26.00 & $38.00^{\mathrm{a}}$ & 0.42 & 0.49 & $29.00^{\mathrm{a}}$ \\
\hline & 8.11 & 10.25 & 24.00 & $38.00^{a b}$ & 0.40 & 0.53 & $27.30^{a b}$ \\
\hline & 10.00 & 9.40 & 23.50 & $37.50^{a b}$ & 0.39 & 0.54 & $26.10^{\mathrm{ab}}$ \\
\hline & 15.00 & 8.00 & 21.00 & $32.75^{b^{*}}$ & 0.38 & 0.50 & $25.00^{b^{*}}$ \\
\hline \multirow{6}{*}{$\begin{array}{l}\text { Sulphate-so } \\
\text { dium } \\
\mathrm{B}^{1^{*}}, \mathrm{~B}^{2^{*}}\end{array}$} & 1.77 & 15.50 & 25.00 & $38.00^{\mathrm{a}}$ & 0.32 & 0.50 & $30.00^{\mathrm{a}}$ \\
\hline & 3.88 & 13.00 & 24.60 & $36.00^{\mathrm{a}}$ & 0.38 & 0.51 & $28.10^{\mathrm{a}}$ \\
\hline & 6.00 & 10.25 & 23.00 & $34.13^{\mathrm{a}}$ & 0.40 & 0.50 & $27.00^{\mathrm{a}}$ \\
\hline & 8.11 & 10.00 & 21.75 & $32.50^{a b}$ & 0.40 & 0.52 & $26.50^{a b}$ \\
\hline & 10.00 & 8.75 & 19.00 & $30.42^{a b}$ & 0.36 & 0.54 & $26.00^{\mathrm{ab}}$ \\
\hline & 15.00 & 6.00 & 18.20 & $27.00^{b^{*}}$ & 0.35 & 0.54 & $23.00^{b^{*}}$ \\
\hline
\end{tabular}

$\S \mathrm{DAE}=$ Days after emergence.

$\mathrm{A}, \mathrm{B}, \mathrm{BA}=$ test of averages between types of salinity for the variables: ${ }^{1}$ plant height $(\mathrm{P}>\mathrm{F}=0.0001)$ and $^{2}$ final root length $(\mathrm{P}>\mathrm{F}=0.0001)$.

$\mathrm{a}, \mathrm{ab}, \mathrm{b}$ : test of averages between EC levels for the variable ${ }^{3}$ plant height $80 \mathrm{DAE}$, and for the variable ${ }^{4}$ final root length $(\mathrm{P}>\mathrm{F}=0.0001)$. Same alphabetica $(\mathrm{a}),(\mathrm{ab})$ indicates no significant difference. $(*)$ Statistical significance on Duncan-test $(\mathrm{P}=0.05)$.

\subsection{Biomass Accumulation in the Canopy}

The proportional accumulation of biomass in potato plants exposed to each salinity experimented was greater in the aerial section than in the underground section. This accumulation accounts for 30 to $35 \%$ of the total dry weight. This variation depends on the type of salinity and EC level. Plants grown in sulphate-hydrochloric conditions reduced their percentage of accumulated biomass with regard to the control $10.97 \%$, while in hydrochloric-sulphate conditions this reduction was $8.62 \%$, with no significant difference between these treatments. Meanwhile the plants in the sulphatic-sodium treatment displayed the lowest averages of dry weight in the aerial section from EC of $6.0 \mathrm{dS} \mathrm{m}^{-1}$ onwards. The reduction of the dry weight of the aerial section in these 
saline conditions is such that it only accounts for $10 \%$ of the accumulated biomass in the aerial section of potato plants grown in rainy conditions, and was between 35 and $40 \mathrm{~g}$ according to data reported by (Mora et al., 2004). This coincides with Strogonov (1964), who points out that plants grown in saline conditions, such as tomato, cotton, barley and wheat (Triticum aestivum L.), considerably reduced the accumulation of dry matter in the aerial section. Likewise, the accumulation of carbohydrates and nitrogenous substances in mature leaves was quicker than their use for the formation of new cells and tissues. Hence their researchers conclude that plants exposed to saline stress transform their leaves into storage organs, reducing the plant's general growth rate. This statement coincides with observations made in the present study. On this, Beringer, Koch, \& Lindhauer (1990) point out that in potato plants, salinity affects the size of the source and its activity by reducing the amount of biomass assigned for the filling and expansion of the tubers and consequently, these organs reduce their growth. This upset in the source-demand ratio was noticed in potato plants grown in conditions of sulphate-hydrochloric and hydrochloric-sulphate salinities, since biomass accumulation in the aerial section was lower than in the tubers; that is, there was a translocation of assimilates to the demand organs but this flow was very limited. It explains the formation of small tubers. The inhibition in the accumulation of biomass in the aerial section was more evident in plants exposed to sulphate-sodium salinity, since at EC higher than $3.88 \mathrm{dS} \mathrm{m}^{-1}$ the formation of tubers stopped. In fact this salinity to an electrical conductivity of $15 \mathrm{dS} \mathrm{m}^{-1}$, showed a significant difference over other treatments, with $\mathrm{P}=0.05$. This implies that the sodium salinities produced a greater imbalance in the source-demand ratio.

\subsection{Biomass Accumulation in the Underground Portion}

The potato plants in conditions of sulphate-hydrochloric and hydrochloric-sulphate salinities accumulated less biomass in the underground portion $(\sim 27 \%$ of the total) due to the natural reduction in the growth of the root, since in the stage of tuber growth there is a translocation of photosynthates from the root to the tubers (Kafkafi \& Bernstein, 1996; Mora et al., 2004). In this case such reduction is due mostly to saline stress, since in these conditions, the root goes from being a growth organ to being a storage organ (Strogonov, 1964; Bahrami \& Razmooj, 2012). The underground organs (root and stolons) in contact with the hydrochloric-sulphate and sulphate-hydrochloric salinities displayed a larger biomass than the control, by $7.16 \%$ and $11.34 \%$ respectively. This is due to an initial nutritious stimulus produced by salt solutions at low concentrations (Sánchez \& Ortega, 2011). The EC that induced a maximum biomass accumulation in the underground section of the potato plants were $8.11 \mathrm{dS} \mathrm{m}^{-1}$ for those grown in hydrochloric-sulphate salinity and $6.0 \mathrm{dS} \mathrm{m}^{-1}$ for those evaluated in sulphate-hydrochloric salinity. This physiologic behavior coincides with the one observed by Strogonov (1964) and Maas and Hoffman (1977) who noted that the processes of growth, development and accumulation of dry matter of barley plants (Hordeum vulgare L.), tomato and cotton, are more frequently affected by the hydrochloride salinity in comparison to the decrease produced by sulphate salinity, which is noticeable as the saline level increases (Table 4). The accumulation of biomass in the root and stolons at high salinity concentrations is considered by Mohammed and Sen (1990) and by Kafkafi and Bernstein (1996) as a mechanism of the radicular system to tolerate stress. The roots use these substances in periods of water availability to grow and avoid excessive salinity. On the other hand, plants in contact with sulphate-sodium salinity displayed the lowest averages of biomass accumulation in underground organs. Statistical analysis indicates significant difference of this treatment over other with $\mathrm{P}=0.05$, especially at $\mathrm{EC}$ above $3.88 \mathrm{dS} \mathrm{m}^{-1}$. In this regard Sánchez et al. (2008) consider that the toxicity of the sodium-alkaline salts affects the metabolism of meristematic cells in a crucial manner, since they tend to cause the death of growth tissues, thus inhibiting the accumulation of biomass.

\subsection{Biomass Accumulated in the Tubers}

The tubers of plants grown in sulphate-hydrochloric and hydrochloric-sulphate salinities accumulated $40 \%$ of the total biomass, with variations dependant on the salinity and EC levels. The saline treatments displayed increases of accumulated biomass in the tubers in comparison to the control in the following order: hydrochloric-sulphate salinity $(11.13 \%)>$ sulphate-hydrochloric salinity $(5.81 \%)$, whereas the sulphate-sodium salinity reduced the accumulation of biomass by $70.26 \%$. The latter displayed a significant difference with $\mathrm{P}=0.05$. Results indicate that in equivalent salinity conditions, sulphate-sodium salinity produces more adverse effects for growth than hydrochloric-sulphate or sulphate-hydrochloric salinities, which corresponds to observations by Sánchez \& Ortega (2011) in evaluations of bud growth in potato tubers cv. Alpha. This also shows that between these two salinities, sulphate-hydrochloric tends to limit more intensely the accumulation of biomass of the demand organs in comparison with that produced by the hydrochloric-sulphate salinity. The differential effect of both types of salinity has been satisfactorily explained by Strogonov (1964), who points out that in conditions of sulphate-hydrochloric salinity, as opposed to hydrochloric-sulphate salinity, the rate of movement of reserve 
material during the autotrophic phase in the growth of potato is very low, and consequently, plant growth is delayed. Therefore small plants develop with scarce productivity. On the other hand, the EC that most favoured biomass accumulation in the tubers were $1.77 \mathrm{dS} \mathrm{m}^{-1}$ for plants grown in sulphate-sodium salinity (at higher EC, tubers stop being formed) and $8.11 \mathrm{dS} \mathrm{m}^{-1}$ for those developed in hydrochloric-sulphate or sulphate-hydrochloric salinities. In general, the dry weights of tubers in these two salinities (13.40 g on average) are very low in comparison with those for commercial potato tubers produced in Mexico that reach weights of up to $80 \mathrm{~g}$ (Mora et al., 2004). Due to this, we asserted that in these saline conditions, the accumulation of dry matter of potato tubers is strongly reduced. Essentially, the effects of salinities in tubers observed in this experiment are: 1) The formation of small potatoes as a consequence of a delay in the growth of the foliar system in both the vegetative state and in the filling of the tuber. The scarce foliar development caused an insufficient supply of nitrogenated substances and carbohydrates to the tubers in formation, which consequently accumulate small amounts of biomass and limit their growth. 2) The physiological phenomenon of secondary tubers, namely that tuber growth stops by effect of salinity stress and when salinity is reduced by irrigation water, conditions are created to resume growth. Although it does not continue in the tubers themselves, since a new tuber is formed in the adjoining axillary buds of the stolon. This is a secondary growth in a chain induced by the periodicity of growth due to saline-water stress present in soils subject to irrigation (Ross \& Davies, 1985; Sánchez et al., 2012). Nadler and Heuer (1998) reported a similar behaviour in potato plants exposed to hydrochloride salinity.

\subsubsection{Effect of Salinity on the Diameter and Number of Tubers}

Basically, the secondary growth in the saline conditions undergone caused the formation of several mini-tubers with scarce accumulated biomass and little commercial value. For example in an interval of EC between 1.77 and $8.11 \mathrm{dS} \mathrm{m}^{-1}$ the average number of tuber per plant induced by sulphate-hydrochloric and hydrodchloric-sulphate conditions was about 12 , of which $75 \%$ had diameters less than $3 \mathrm{~cm}$, while the remaining $25 \%$ showed more than $3 \mathrm{~cm}$ up to $5.5 \mathrm{~cm}$ of diameter. The major dimensions were common to low levels of salts. The phenomenon was more adverse in sulphate-sodium salinity conditions, since at EC $>3.88 \mathrm{dS}$ $\mathrm{m}^{-1}$ they were no longer formed. Comparing these results with those obtained by Sanchez et al. (2008) with potato plants cv. Alpha grown in pure saline solutions of $\mathrm{NaCl}, \mathrm{MgCl}_{2} \cdot 6 \mathrm{H}_{2} \mathrm{O}, \mathrm{NaHCO}_{3}, \mathrm{Na}_{2} \mathrm{SO}_{4}, \mathrm{CaCl}_{2} \cdot 2 \mathrm{H}_{2} \mathrm{O}$ and $\mathrm{MgSO}_{4} \cdot 7 \mathrm{H}_{2} \mathrm{O}$ at concentrations $>2 \mathrm{~g} \mathrm{~L}^{-1}$, is evident that $\mathrm{cv}$. Alpha and $\mathrm{cv}$. Tollocan have a certain similarity in their response to salinity conditions. Probably this poor tolerance to salt stress is related to the duration of the intermediate life cycle of cv. Tollocan. This coincides with the observations of Levy (1994) in fourteen potato cultivars undergoing in saline solutions of $\mathrm{NaCl}$ and $\mathrm{CaCl}_{2} \cdot 2 \mathrm{H}_{2} \mathrm{O}$, who noted that short-cycle varieties tolerate more salinity than late varieties because their rapid growth allows them to spend less time exposed to extreme saline conditions. Growth differences between varieties were also reported by Gmelig \& Bodlaender (1981).

\subsection{Osmotic Potential of the Saline Solutions and Total Biomass Accumulated}

Experimental salinities reduced the osmotic potential of the saline solutions by increasing their EC levels, which is due to the reduction in the water's chemical activity produced by solutes, a phenomenon that induces physiological drought or water stress in plants grown in saline solutions (Hopkins, 1995; Gomathi, Vasantha, \& Thandapani, 2011). The order of such a reduction was: sulphate-sodium salinity $(-0.60 \mathrm{MPa})>$ sulphate-hydrochloric salinity $(-0.52 \mathrm{MPa})>$ hydrochloric-sulphate salinity $(-0.40 \mathrm{MPa})$. Likewise, the sulphate-sodium salinity reduced the average total dry weight of the plants the most, with values of $12.47 \mathrm{~g} \mathrm{pl}^{-1}$, followed by the hydrochloric-sulphatic salinity, with $34.69 \mathrm{~g} \mathrm{pl}^{-1}$ and sulphatic-hydrochloric salinity with $33.12 \mathrm{~g}$ $\mathrm{pl}^{-1}$, indicating that the osmotic-toxic effect of the sodium alkaline salts affects the production of biomass in potato plants more intensely than hydrochloric-sulphatic and sulphatic-hydrochloric salinities. This is consistent with observations by Sanchez et al. (2008), who considered that in potato plants, the osmotic-toxic effect of salts such as $\mathrm{NaHCO}_{3}$ is more harmful than the purely osmotic effect of the salts $\mathrm{NaCl}$ and $\mathrm{Na}_{2} \mathrm{SO}_{4}$. The reduction of the total biomass accumulated in the potato plants evaluated can also be explained with a statement by Gorham (1996), who argues that under water-saline stress, plants with a C3 metabolism, such as potatoes, close their stomata to avoid cellular dehydration. This causes a reduction in photosynthetic production, and as a consequence, the accumulation of biomass in the plant organs is affected and growth is reduced. 
Table 4. Effect of the experimental salinities and their concentrations in the biomass accumulation of potato plants cv. Tollocan

\begin{tabular}{|c|c|c|c|c|c|c|c|c|}
\hline Salinity & $\begin{array}{l}\text { EC } \\
d S m^{-1}\end{array}$ & $\begin{array}{l}\text { Dry } \\
\text { weight } \\
\text { root, } \\
\text { stolons } \\
\text { (g) }\end{array}$ & $\begin{array}{l}\text { Dry } \\
\text { weight } \\
\text { aerial } \\
\text { section } \\
\text { (g) }\end{array}$ & $\begin{array}{l}\text { Dry } \\
\text { weight } \\
\text { tubers } \\
\text { (g) }\end{array}$ & $\begin{array}{l}\text { Total } \\
\text { dry } \\
\text { weight } \\
\text { (g) }\end{array}$ & $\begin{array}{l}\text { Proportional } \\
\text { accumulation } \\
\text { of biomass } \\
\text { Root }\end{array}$ & $\begin{array}{l}\text { Proportional } \\
\text { accumulation } \\
\text { of biomass } \\
\text { Aerial } \\
\text { section }\end{array}$ & $\begin{array}{l}\text { Proportional } \\
\text { accumulation } \\
\text { of biomass } \\
\text { Tubers }\end{array}$ \\
\hline Control & 0.00 & 8.81 & 11.05 & 12.35 & $32.21^{\mathrm{a} / 2}$ & 0.27 & 0.34 & 0.38 \\
\hline \multirow{6}{*}{$\begin{array}{l}\text { Sulphate- } \\
\text { hydrochloric } \\
\mathrm{A}^{1}\end{array}$} & 1.77 & 10.20 & 12.48 & 14.55 & $37.23^{\mathrm{a}}$ & 0.27 & 0.33 & 0.39 \\
\hline & 3.88 & 10.22 & 12.70 & 14.41 & $37.33^{\mathrm{a}}$ & 0.27 & 0.34 & 0.38 \\
\hline & 6.00 & 10.77 & 12.63 & 14.52 & $37.92^{\mathrm{a}}$ & 0.28 & 0.33 & 0.38 \\
\hline & 8.11 & 9.50 & 10.62 & 12.00 & $30.37^{\mathrm{a}}$ & 0.28 & 0.32 & 0.40 \\
\hline & 10.0 & 8.40 & 9.25 & 11.83 & $28.88^{\mathrm{a}}$ & 0.29 & 0.31 & 0.40 \\
\hline & 15.0 & 7.56 & 8.16 & 11.10 & $26.82^{\mathrm{a}}$ & 0.28 & 0.30 & 0.41 \\
\hline \multirow{6}{*}{$\begin{array}{l}\text { Hydrochlo } \\
\text { ricsulphate } \\
\mathrm{A}^{1}\end{array}$} & 1.77 & 10.59 & 12.37 & 14.11 & $37.07^{\mathrm{a}}$ & 0.28 & 0.33 & 0.38 \\
\hline & 3.88 & 10.50 & 12.95 & 14.50 & $37.95^{\mathrm{a}}$ & 0.27 & 0.34 & 0.38 \\
\hline & 6.00 & 10.26 & 12.07 & 14.26 & $35.49^{\mathrm{a}}$ & 0.25 & 0.34 & 0.40 \\
\hline & 8.11 & 10.80 & 11.41 & 13.80 & $34.33^{\mathrm{a}}$ & 0.26 & 0.33 & 0.40 \\
\hline & 10.0 & 9.45 & 10.83 & 13.20 & $32.48^{\mathrm{a}}$ & 0.26 & 0.33 & 0.40 \\
\hline & 15.0 & 8.35 & 10.14 & 12.65 & $30.84^{\mathrm{a}}$ & 0.26 & 0.32 & 0.41 \\
\hline \multirow{6}{*}{$\begin{array}{l}\text { Sodium- } \\
\text { sulphate } \\
\mathrm{B}^{1}\end{array}$} & 1.77 & 7.18 & 8.54 & 11.00 & $26.72^{\mathrm{a}}$ & 0.26 & 0.31 & 0.41 \\
\hline & 3.88 & 5.40 & 6,33 & 6.12 & $17.85^{\mathrm{ab}}$ & 0.30 & 0.35 & 0.34 \\
\hline & 6.00 & 3.80 & 4.45 & 3.50 & $11.75^{a b}$ & 0.32 & 0.37 & 0.29 \\
\hline & 8.11 & 2.57 & 3.04 & 2.90 & $8.51^{\mathrm{ab}}$ & 0.30 & 0.35 & 0.34 \\
\hline & 10.0 & 2.27 & 2.04 & 1.38 & $5.69^{b^{*}}$ & 0.39 & 0.35 & 0.24 \\
\hline & 15.0 & 2.30 & 1.90 & 0.15 & $4.35^{b^{*}}$ & 0.52 & 0.43 & 0.03 \\
\hline
\end{tabular}

Note: Average of six plants per treatment and concentration level.

$\mathrm{A}, \mathrm{B}=$ Test of averages between treatments for the variable: ${ }^{1}$ total dry weight $(\mathrm{Pr}>\mathrm{F}=0.0001)$.

$a, b, a b=$ Test of averages between EC levels for the variable: ${ }^{2}$ total dry weight. Same alphabetica (a), (ab) indicates no significant difference. $\left({ }^{*}\right)$ Statistical significance on Duncan-test $(\mathrm{P}=0.05)$.
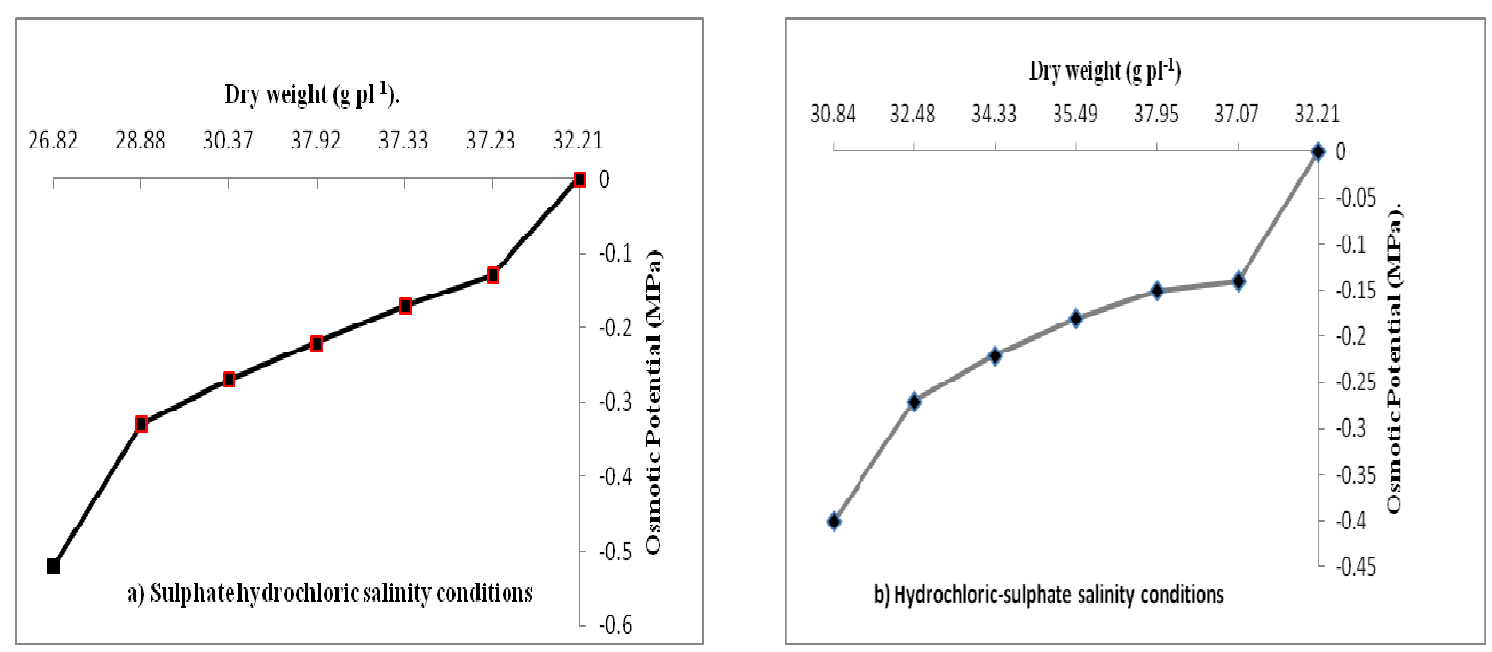


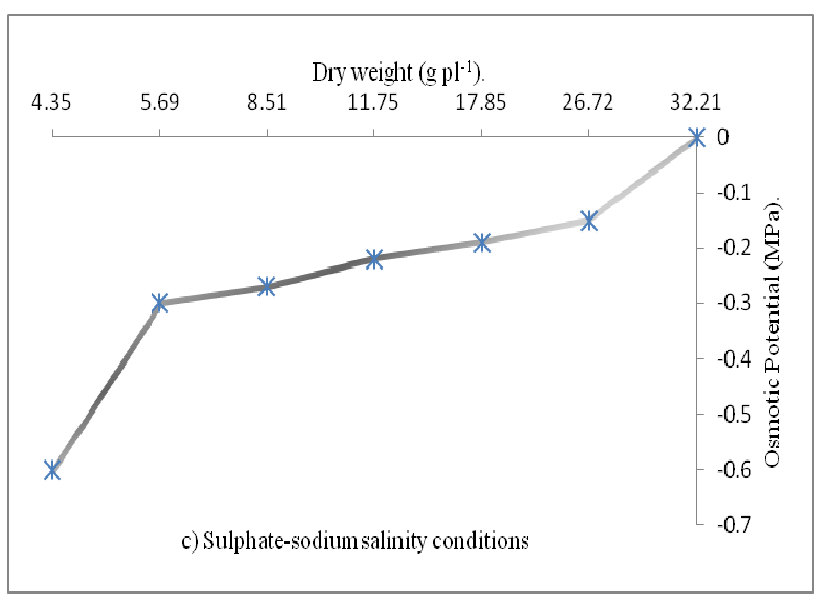

Figure 1. Biomass accumulation of S. tubersoum L. cv.Tollocan, induced by osmotic potential of each salinity

\subsection{Mathematical Estimation of the Total Dry Weight of Plants}

Table 5 shows the equations for the estimation of the total dry weight of potato plants cv. Tollocan based on the osmotic potential generated by the three types of salinity at $\mathrm{EC}$ of 1.77 to $15.0 \mathrm{dS} \mathrm{m}^{-1}$. These equations predict that at equal amounts of saline concentrations, the reduction of the osmotic potential produced by the sulphate-hydrochloric and hydrochloric-sulphate salinities would not reduce the total dry weight of the plants in comparison to the control. On the contrary, it increased it slightly, indicating that the growth was less affected by both salinities. Despite this, the accumulation accounts for only $46 \%$ of the accumulation of biomass obtained from cv. Lupita and cv. Atzimba potato plants in rainy conditions (Borrego et al., 2000). On the other hand, the potato plants in sulphate-sodium salinity had the highest reduction of the total dry weight, which is related to the excessive decrease of osmotic potential produced by this salinity in the solution and by the toxicity of the sodium-alkaline conditions generated in the growth medium, to which plants of S. Tuberosum, L. cv. Tollocan are very sensitive.

Table 5. Models for determining the total dry weight of the potato plants, based on the osmotic potential of saline solutions

\begin{tabular}{lllll}
\hline Type of Salinity & Equation & $\mathrm{R}$ & $\mathrm{R}^{2}$ & $\mathrm{CV}$ \\
\hline Sulphate-hydrocloric & $T D W(g)=41.62+(31.23)(\Psi \pi)$ & 0.88 & 0.77 & 0.15 \\
Hydrochloric-sulphate & $T D W(g)=40.67+(26.38)(\Psi \pi)$ & 0.94 & 0.90 & 0.08 \\
Sulphate-sodium & $T D W(g)=23.45+(38.05)(\Psi \pi)$ & 0.72 & 0.52 & 0.68 \\
\hline
\end{tabular}

Where: TDW $=$ Total dry weight. $\Psi \pi=$ Osmotic potential of saline solution.

\subsection{Predicting the Biological Yield of Potato Plants under Experimental Saline Conditions}

Biological yield is the sum of the biomass accumulated in the different organs of a plant (Donald \& Hamblin 1976). Therefore in the potato, it is the sum of the dry weight of the underground organs (roots, stolons and tubers) + the dry weight of the aerial section (stems and leaves), with values that are shown in Table 4 . We observe that for plants grown in sulphate-hydrochloric and hydrochloric-sulphate conditions, in an interval of EC of 1.77 to $6.0 \mathrm{dS} \mathrm{m}^{-1}$ in salt solution, average yield was $37.49 \mathrm{~g} \mathrm{pl}^{-1}$ in the former salinity and $36.83 \mathrm{~g} \mathrm{pl}^{-1}$ in the latter, respectively. Whereas for plants grown in sulphate-sodium salinity, biological yield for that saline interval was $18.77 \mathrm{~g} \mathrm{pl}^{-1}$. These values account for $46.86 \%, 46.03 \%$ and $23.46 \%$ in terms of the biological yield for this variety established by Mora et al. (2004) in rainy conditions, which is $80 \mathrm{~g} \mathrm{pl}^{-1}$. The average yields obtained in the interval of saline concentration $\left(8.11\right.$ to $\left.15 \mathrm{dS} \mathrm{m}^{-1}\right)$ are even lower $(28.69 \%$ in the sulphate-hydrochloric salinity, $32.55 \%$ in the sulphate-hydrochloric salinity and $6.18 \%$ in sulphate-sodium salinity, respectively). When introducing these yields into the equation $b=\frac{100}{C E_{s} \text { para } Y=0 \%-\left(S_{u}\right)}$ and $\mathrm{Y}=100-\mathrm{b} \cdot \mathrm{CEs}-\mathrm{A}$, values were obtained indicating a reduction of BY for potato plants in experimental salinity conditions and EC levels shown in Table 6, in which it is observed that plants grown in hydrochloric-sulphate and sulphate-hydrochloric salinities reduced their yield $\sim 40 \%$ with an EC interval from 1.77 to $3.88 \mathrm{dS} \mathrm{m}^{-1}$ and $\sim 70 \%$ with an EC interval 
from 3.88 to $6.0 \mathrm{dS} \mathrm{m}^{-1}$. Therefore according to the classification by Mass and Hoffman (1977), they are considered sensitive to these salinities and levels of EC. At EC $>6.00 \mathrm{dS} \mathrm{m}^{-1}$ BY dropped $\sim 100 \%$ indicating that S. Tuberosum L.cv. Tollocan cannot tolerate these salinity levels. A drop by $60 \%$ of BY was registered at the EC interval from 1.77 to $3.88 \mathrm{dS} \mathrm{m}^{-1}$ for potato plants grown in sulphate-sodium salinity, which indicates they are hypersensitive to this salinity. To higher salinity levels, biological yield completely atrophies.

Table 6. Reduction of the BY in cv. Tollocan potato plants according to the type of salinity and EC level of the solution

\begin{tabular}{llllllllll}
\hline Salinity & \multicolumn{3}{c}{ Interval of ECs $\left(\mathrm{dS} \mathrm{m}^{-1}\right)$} & \multicolumn{4}{c}{ \% reduction of the biological yield Tolerance level } \\
& Level 1 & Level 2 & Level 3 & Level 1 & Level 2 & Level 3 & 1 & 2 \\
\hline Hydrochloric-sulphate & $(1.77,3.88]$ & $(3.88,6.0]$ & $(6.0,8.11]$ & 44.70 & 68.48 & 99.96 & S & ES NT \\
Sulphate-hydrochloric & $(1.77,3.88]$ & $(3.88,6.0]$ & $(6.0,8.11]$ & 40.00 & 62.20 & 99.96 & S & ES NT \\
Sulphate-sodium & $(1.77,3.88]$ & $(3.88,6.0]$ & $(6.0,8.11]$ & 60.00 & 97.80 & 100.0 & ES & ES NT \\
\hline
\end{tabular}

$\mathrm{S}=$ Sensitive, $\mathrm{ES}=$ Extremely sensitive, $\mathrm{NT}=$ Intolerant.

Our results indicate that in the experimental saline conditions, the photosynthetic activity of S. tuberosum cv. Tollocan was unaffected during tuberization. However, the absence of tuberization in plants subjected to sodium sulphate salinity and secondary tuber produced under conditions of sulphate hydrochloric and hydrochloric sulphate salinities at levels $>2.48 \mathrm{~g} \mathrm{~L}^{-1}$ verifies our hypothesis that the different types of salinity produced differential effects on the growth of this potato variety. It also shows that the potato plants respond to salt stress with altered physiological conditions consisting in an inefficient partitioning of assimilates to the different parts of the plant, as there is a flow reduction of photosynthates from the leaves to foliar and tubers growing, which explains the reduction of plant foliar system and formation of minitubers. In the present study it was evident that the three experimental salinities at EC levels above $3.88 \mathrm{dS} \mathrm{m}^{-1}$ restrict the growth and development of potato plants cv. Tollocan by osmotic and toxic effects. Thereupon the buildup of salts and predominance of each salinity in upper soil thickness where roots grow potatoes, (a process induced by underground irrigation water), may exceed the threshold of tolerance of cv. Tollocan to salt stress, therefore their growth and development can be seriously affected. This certainly causes losses for producers in these regions, who are forced to open new lands for cultivation. We therefore consider that these results are important for advisors and producers of potato in Mexico, to conduct monitoring of soil and water salinity and detect EC greater than $3 \mathrm{dS} \mathrm{m}^{-1}$ in soil solution and before potato planting, should proceed to implement saline control techniques such as: a) the use of irrigation water with low salt concentration, b) the establishment of artificial drainage, c) application of hydrochemical methods like salt lixiviation and chemical enhancers, and d) grow potato varieties of some tolerance to salinity as proposed by Levy and Veilleux (2007) and Mudgal et al. (2010). From these results we conclude that: (1) High levels of salinity reduce the partitioning of assimilates to the tubers. This physiological disorder is higher in plants subjected to sulphate-sodium salinity to EC $>1.77 \mathrm{dS} \mathrm{m}^{-1}$ from which tuberization was inhibited. So S. tuberosum cv. Tollocan is considered extremely sensitive to this salinity. (2) potato plants grown in sulphate- hydrochloric and hydrochloric-sulphate salinities produced a less adverse effect on the efficiency physiological of this variety since they accumulated more biomass than those grown in sulphate-sodium salt at an EC of $3.88 \mathrm{dS} \mathrm{m}^{-1}$ in the saline solution and therefore is considered sensitive to both salinities, (3) degrading scheme produced by experimental salinities in potato plants can be controlled by agronomic preventive actions such as temporary leaching of salts from the rhizosphere, the establishment of artificial drainage, and the use of chemical enhancers and cultivation of potato varieties tolerant to each type of salinity.

\section{Acknowledgements}

We thank to Universidad del Mar and Water Sciences Program of Colegio de Postgraduados, for providing us with much needed assistance.

\section{References}

Aguilar, A. J., López, M. R., Núñez, E. R., \& Khalil, G. A. (2003). Liming and P fertilization on potato growth in an Andosol of the Sierra Veracruzana. Terra Latinoamericana, 21, 417-426. 
Baharami, H., \& Razmjoo, J. (2012). Effect of salinity stress ( $\mathrm{NaCl})$ on germination and early seedling growth of ten sesame cultivars (Sesame indicum L.). Int. J. of Agri Science, 2(6), 529-537.

Beringer, H., Koch, K., \& Lindhauer, M. G. (1990). Source: sink relationships in potato (Solanum tuberosum) as influenced by potassium chloride or potassium sulphate nutrition. In Plant nutrition-physiology and applications (pp. 639-642). Norwell, Massachusetts: Klewer Academic Press. http://dx.doi.org/10.1007/978-94-009-0585-6_107

Bernstein, L. (1964). Salt tolerance of plants. Information Bulletin 283. US Department of Agriculture. Washington D C, USA, p. 323.

Borrego, F., Fernandez, M., Lopez, A., Parga, M., Murillo, M., \& Carbajal, A. (2000). Analysis of growth in seven potato varieties (Solanum tuberosum L.). Agron. Mesoamericana, 11, 145-149.

De la Casa, A., Ovando, G., Bressanini, L., Rodríguez, A., Martínez, J. (2007). Using leaf area index and percentage ground cover to estímate the interception of radiation in potato. Agr. Tec., 67, 78-85.

Donald, C. M., \& Hamblin, J. (1976). The biological yield and harvest index of cereals as agronomic and plant breeding criteria. Adv. Agron., 28, 361-405. http://dx.doi.org/10.1016/S0065-2113(08)60559-3

Food and Agriculture Organization of the United Nations. (2008). New light on a hidden treasure. International Year of The Potato. New York, USA: FAO-UNESCO.

Gmelig, M. H., \& Bodlaender, K. B. (1981). Varietal differences in growth, development and tuber production of potatoes. Net. J. Agric. Sci., 29, 113-127.

Gorham, J. (1996). Mechanisms of salt tolerance of halophytes. In Coukr-Allah, R., Malcom, C. V., \& Hamdy, A. (Eds.), Halophytes and Biosaline Agriculture (pp. 31-53). Nueva York: Marcel Decker Inc.

Gomathi, R. \& Vasantha, S., \& Thandapani, V. (2011). Mechanism of osmo regulation response to salinity stress in sugarcane. Sugar Tech, 12, 305-311. http://dx.doi.org/ 10.1007/s12355-012-0156-y):261-265

Hopkins, G. W. (1995). Introduction to Plant Physiology (2nd ed.). New York: John Wiley \& Sons.

Hunt, R. (1982). Plant growth Curves. London: Arnold.

Iwama, K. (2008). Physiology of the potato: New insights into root system and repercussions for crop management. Potato Res., 51, 333-353. http://dx.doi.org/10.1007/s11540-008-9120-3

Kafkafi, U., \& Bernstein, N. (1996). Root growth under salinity stress. In Y. Waisel, A. Eshel, U. Kafkafi, \& N. Bernstein (Eds.), Plant Roots: The Hidden Half (pp. 435-451). New York: Decker.

Kovda ,V. A. (1977). Arid land irrigation and soil fertility. Problems of salinity, alkalinity and compaction. In Arid Land Irrigation in Developing Countries. New York: Pergamon.

Khurana, S. C., \& McLaren, J. S. (1982). The influence of leaf area, light interception and season on potato growth and yield. Potato Res., 25, 329-342. http://dx.doi.org/10.1007/BF02357290

Ku, S., Edwards, G. E., \& Tanner, C. B. (1977). Effects of light, carbon dioxide and temperature on photosynthesis, oxygen, inhibition of photosynthesis and transpiration in Solaumn tuberosum. Plant Physiol., 59, 868-872. http://dx.doi.org/10.1104/pp.59.5.868

Levy, D. (1994). The response of potatoes (Solanum tubersoum L.) to salinity: plant growth and tuber yields in the arid desert of Israel. Ann. Appl. Biol., 120, 547-555. http://dx.doi.org/10.1111/j.1744-7348.1992.tb04914.x

Levy, D., \& Veilleux, R. E. (2007). Adaptation of potato to high temperatures and salinity-A Review. Amer J. of Potato Res., 84, 487-506. http://dx.doi.org/10.1007/BF02987885

López, R. E. (1993). Geology general and Mexico. (7ª edic.) México. Trillas.

Maas, E. V., \& Hoffman, G. J. (1977). Crop salt tolerance current assessment. J. Irrig. Drain. Div., 103, 115-154.

Milthorpe, F. L. (1993). Some aspects of plant growth. In J. D. Evins \& F. Milthorpe (Eds.). The Growth of the Potato (pp. 3-20). London: Butterworth.

Mohamed, S., \& Sen, D. N. (1990). Germination behavior of some halophytes in Indian desert. Ind. J. Expt. Biology., 28, 545-549.

Moorby, J., \& Milthorpe, F. L. (1983). Potato. In L T Evans (Ed.). Crop Physiology. (pp. 220-257). Buenos Aires, Argentina: Hemisferio Sur. 
Mora, A, R., Rodríguez, P. J., Pena, L. A., \& Campos, D. A. (2004). Osmotic conditioning of potato (Solanum tuberosum L.) seed with saline solutions. Chapingo Rev. Hórtico. Ser., 10, 15-21.

Moran, Z. D. (1994). The Geology of the Mexican Republic. (1 ${ }^{\mathrm{a}}$ edic.) Tulsa, OK. American Association of Petroleum Geologists .

Mudgal, V., Madaan, N., \& Mudgal, A. (2010). Biochemical mechanisms of salt tolerance in plants. A Review. Int. J. Bot., 6, 136-143. http://dx.doi.org/10.3923/ijb.2010.136.143

Nadler, A., \& Heuer, B. (1998). Physiological response of potato plants to soil salinity and water deficit. Plant Sci., 137, 43-51. http://dx.doi.org/10.1016/S0168-9452(98)00133-2

Ortega, E. M., Ramírez, M. O., Ontiveros, A. C., \& Rone, J. (1989). Determining the germination of some agricultural crops in saline solutions of varying concentration and composition qualitatively. Agrociencia, $78,249-264$.

Poljakoff, A., \& Lerner, R. H. (1994). Plants in saline environments. In A. Pessarakli (Ed.), Handbook of Plant and Crop Stress (pp. 65-96). New York: Decker.

Prange, R. K., McRae, K. B., Midmore, D. J., \& Peng, R. (1990). Reduction in potato growth at high temperature: role of photosynthesis and dark respiration. Am. J. Bot., 67, 357-359.

Pyung, O. L., Kim, H. J., \& Nam, H. G. (2007). Leaf senescense. Ann R. of Pl. Biol., 58, 115-136. http://dx.doi.org/ 10.1146/annurev.arplant.57.032905.105316

Rahman, M. H., Islam, R., Hossain, M., \& Haider, S. A. (2008). Differential response of potato under sodium chloride stress conditions in vitro. J. bio-sci., 16, 79-83. http://dx.doi.org/ 10.3329/jbs.v16i0.3745

Ross, A., \& Davies, V. (1985). The formation and development of Adventitious Buds on Potato Sprouts. Ann. of Bot., 56, 741-744.

Rousselle, P., \& Robert, J. C. (1996). La pomme de terre. Institut National de la Recherche Agronomique. París.

Sánchez, B. E., Ortega, E. M., González, H. V., Ruelas, A. G., Kohashi, S. J., \& Calderón, N. G. (2003). Tolerance of potato tubers cv. Alpha in sprouting stage to salinity stress. Terra, 21, 481-491.

Sánchez, B. E., Ortega, E. M., Gonzalez, H. V., Camacho, E. M., \& Shibata, J. K. (2008). Growth of potato plants (Solanum tuberosum L.) cv. Alpha induced by diverse salinity conditions. Interciencia, 33, 643-650.

Sánchez, B. E., \& Ortega, E. M. (2011). Emergence of potato tuber sprouts in salinity conditions. Terra Lat., 29,153-160.

Sánchez, B. E., Camacho, E. M., Rodriguez, L. A., \& Ortega, E. M. (2012). Characterization of soils affected by salts in irrigation district 110 "Río Verde", Oaxaca, Mexico. AJAR., 7(6), 943-957. http:// dx.doi.org/10.5897/AJAR11.1479

Sánchez, B. E., Ortega, E. M., Sandoval, O. G., Viruel, H. R., \& Estrada, V. C. (2012). Salt lixiviation in coastal alluvial soils of Oaxaca, Mexico, with treated municipal wastewater. RICA, 28(4), 343-360.

Statistical Analysis System Institute. (2006). User's guide Release 0.13 Statistics. SAS Institute Cary N C, USA.

Steiner, A. A. (1984). The universal nutrient solution. Proc. 6th Intern. Congress on Soilles Culture. International Society for Soilless Culture. pp. 634-649.

Strogonov, B. P. (1964). Physiological basis of salt tolerance of plants. (As affected by various types of salinity). Academic of Sciences, USRR/ Israel Program for Scientific Translations. Jerusalem. p. 256.

Watson, D. J. (1947). Comparative physiological studies on the growth of field crops. I. Variation in net assimilation rate and leaf area between species and varieties, and within and between years. Ann Bot., 11, 41-76.

Wolf, S. (1993). Effect of leaf age on photosynthesis, carbon transport and carbon allocation in potato plants. Potato Res., 36, 253-262. http://dx.doi.org/10.1007/BF02360534 